www.nature.com/ja

\title{
Two new doramectin analogs from Streptomyces avermitilis NEAU1069: fermentation, isolation and structure elucidation
}

\author{
Xiang-Jing Wang ${ }^{1}$, Ji-Jia Wang ${ }^{1}$, Ji-Dong Wang ${ }^{2}$, Ji Zhang ${ }^{1}$, Mei-Dong $\mathrm{Xu}^{2}$ and Wen-Sheng Xiang ${ }^{1}$
}

The Journal of Antibiotics (2011) 64, 591-594; doi:10.1038/ja.2011.48; published online 15 June 2011

Keywords: new doramectin analogs; Streptomyces avermitilis NEAU1069; structure elucidation

Microbes have made a phenomenal contribution to the health and well-being of people throughout the world. ${ }^{1}$ Nowadays, drug discovery from microbial natural products has become more and more difficult. However, it is not the end of an era but an endless frontier. ${ }^{2}$ To explore more bioactive compounds, a strain of Streptomyces avermitilis NEAU1069 that produced milbemycins was isolated from a soil sample. ${ }^{3}$ Later, two novel macrolide compounds with a cyclohexyl group at the position of C-25, such as doramectin and avermectin $\mathrm{B} 1 \mathrm{a}$, were obtained from the fermentation broth, using bioactivity guided fractionation method, on adding cyclohexanecarboxylic acid to the fermentation medium. ${ }^{4}$ The co-existence of milbemycins and avermectin implies that $S$. avermitilis NEAU1069 is an interesting strain and merits further study. Therefore, large amounts of fermentation broth (301) were collected and the detailed constituents were investigated; two other new compounds 1 and 2 (Figure 1), similar to doramectin, were subsequently obtained. Here we describe the fermentation, isolation and structure elucidation of these two new doramectin analogs 1 and 2.

Compound 1 was obtained as a white amorphous powder. Its molecular formula was established to be $\mathrm{C}_{44} \mathrm{H}_{68} \mathrm{O}_{11}$ as deduced from the high-resolution electron spray ionization (HRESI)-MS and ${ }^{13} \mathrm{C}$ NMR data (Table 1). The IR spectrum of 1 showed absorption bands assignable to the hydroxyl group $\left(3447 \mathrm{~cm}^{-1}\right)$ and an ester carbonyl $\left(1705 \mathrm{~cm}^{-1}\right)$. The ${ }^{1} \mathrm{H}$ NMR $\left(400 \mathrm{MHz}, \mathrm{CDCl}_{3}\right)$ data (Table 1) of 1 displayed three doublet aliphatic methyls at $\delta 0.90$, $1.18,1.28$; three olefinic methyl signals at $\delta 1.55,1.72,1.82$; two methoxy signals at $\delta 3.37,3.51$; one trans-double bond at $\delta 5.59$ (dd, $J=10.0,14.8 \mathrm{~Hz}$ ) and $\delta 6.00\left(\mathrm{dd}, J=10.8,14.8 \mathrm{~Hz}\right.$ ). Its ${ }^{13} \mathrm{C}$ NMR spectrum revealed 44 carbon resonances, including an ester carbonyl carbon at $\delta 174.1(\mathrm{~s})$, a ketal carbon at $\delta 99.6(\mathrm{~s}), 5 s p^{2}$ methines, $3 s p^{2}$ quaternary carbons, 3 secondary methyls, 3 vinylic methyls, 11 methylenes, 14 aliphatic methines (10 oxygenated), 1 oxygenated quaternary carbon and 2 methoxy groups. The above data accounted for
65 protons, indicating the presence of three free hydroxyl groups in 1. Comparison of the ${ }^{1} \mathrm{H}$ NMR data of 1 with those of selamectin ${ }^{5}$ and doramectin ${ }^{6}$ suggested that compound $\mathbf{1}$ was structurally related to doramectin and selamectin (Figure 1). The differences between 1 and selamectin were in C-5, C-6, C-8 and C-23. The ${ }^{1} \mathrm{H}_{-}{ }^{1} \mathrm{H}$ COSY and $\mathrm{HMBC}$ spectra (Figure $1 \mathrm{~b}$ ) fulfilled the assignment of the structure of 1 . The observed HMBC correlations from $\delta_{\mathrm{H}} 1.82$ $(4-\mathrm{Me})$ and one of methoxy proton signal to C-5 ( $\delta$ 77.2) demonstrated that the hydroxyimino group in selamectin was replaced by a methoxy group in 1 . The correlation of $\mathrm{H}-5$ and $\mathrm{H}_{2}-6$ in the ${ }^{1} \mathrm{H}-{ }^{1} \mathrm{H}$ COSY spectrum showed the C-6 was a methylene. The HMBC correlations between $\delta_{\mathrm{H}} 1.72(8-\mathrm{Me})$ and $\delta_{\mathrm{C}} 76.2(\mathrm{~s}, \mathrm{C}-7), \delta_{\mathrm{C}} 136.8$ (s, C-8), $\delta_{\mathrm{C}} 124.6$ (d, C-9) revealed a methyl group was substituted at C-8. A hydroxyl group attached to C-23 was also supported by the $\mathrm{HMBC}$ correlation from the $\delta_{\mathrm{H}} 0.90(24-\mathrm{Me})$ to $\delta_{\mathrm{C}} 70.0(\mathrm{~d}, \mathrm{C}-23)$. As a consequence, the gross structure of 1 was established.

The relative stereochemistry of $\mathbf{1}$ was assigned on the basis of the concurrence with those of doramectin and 25-cyclohexylavermectin $\mathrm{B}_{2}{ }^{6}$

To confirm the assignment of the sugar moiety of $\mathbf{1}$, acid hydrolysis of 1 was performed, and afforded an aglycone and a sugar. The sugar component was identified by TLC co-chromatography with the sugar obtained by acid hydrolysis of selamectin. The identical $R_{\mathrm{F}}$ values of the two resulting sugars indicated that compound $\mathbf{1}$ and selamectin possessed the same sugar moiety.

Compound 2 was obtained as a white amorphous powder. Its molecular formula was established to be $\mathrm{C}_{43} \mathrm{H}_{62} \mathrm{O}_{10}$ on the basis of HRESI-MS at $\mathrm{m} / z 761.4225[\mathrm{M}+\mathrm{Na}]^{+}$(calculated as 761.4235 for $\mathrm{C}_{43} \mathrm{H}_{62} \mathrm{NaO}_{10}$ ). The ${ }^{1} \mathrm{H}$ NMR spectrum of 2 displayed a methoxy group at $\delta 3.52$ and two downfield proton signals at $\delta 6.62,7.40$. Its ${ }^{13} \mathrm{C}$ NMR spectrum showed 43 carbon resonances, including 7 methyls (1 oxygenated), 10 methylenes, 12 aliphatic methines (9 oxygenated), $12 s p^{2}$ carbons, a ketal carbon and an ester carbonyl group. This suggested

${ }^{1}$ Life Science \& Biotechnology Research Center, School of Life Science, Northeast Agricultural University, Harbin, China and ${ }^{2}$ Department of New Drug Screening, Zhejiang Hisun Pharmaceutical, Co. Ltd., Zhejiang, China

Correspondence: Professor W-S Xiang, School of Life Science, Northeast Agricultural University, Harbin 150030, China

E-mail: xiangwensheng@yahoo.com.cn

Received 5 October 2010; revised 20 February 2011; accepted 19 May 2011; published online 15 June 2011 


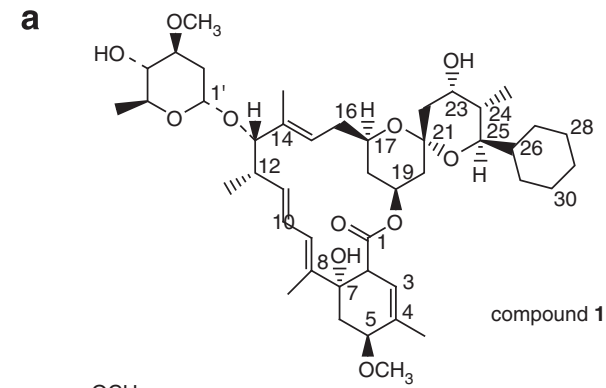

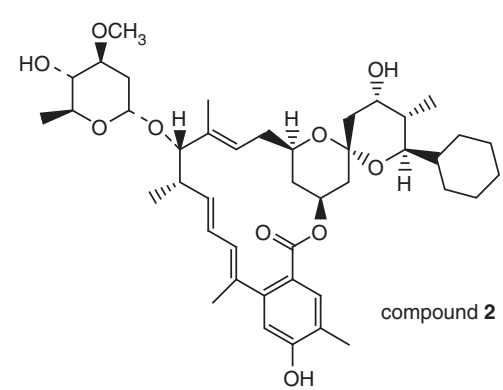

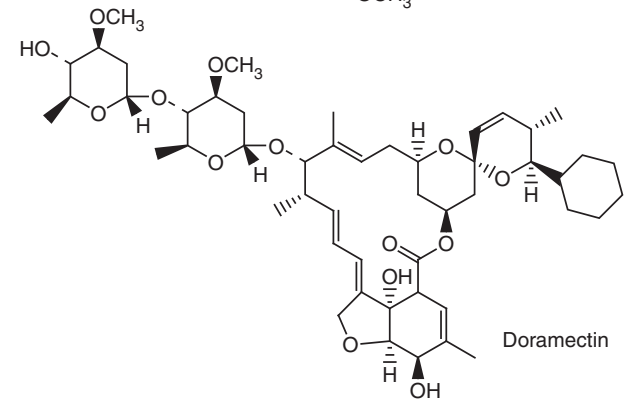

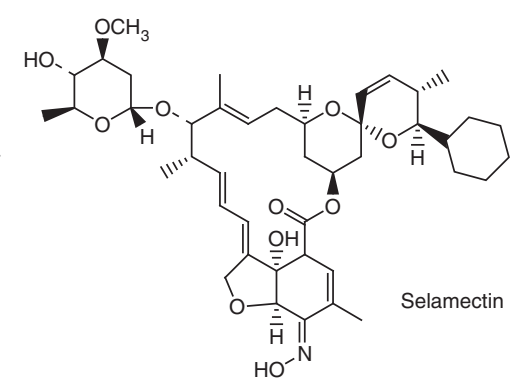

b

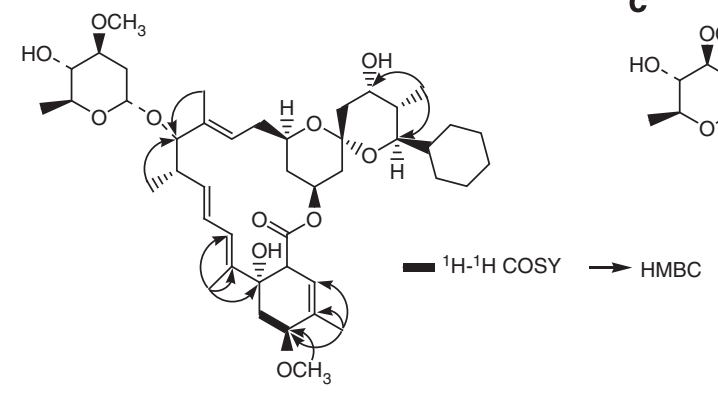

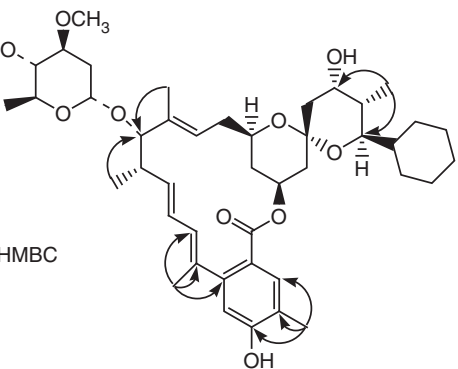

Figure 1 Structures (a) and key ${ }^{1} \mathrm{H}^{1}{ }^{1} \mathrm{H}$ COSY, HMBC correlations (b, c) of compounds 1 and 2.

that 2 was also a doramectin derivative. Comparison of the ${ }^{1} \mathrm{H}$ and ${ }^{13} \mathrm{C}$ NMR data of $\mathbf{2}$ with those of $\mathbf{1}$, the differences between $\mathbf{2}$ and $\mathbf{1}$ were in C-2 to C-7 moiety in addition to the absence of a methoxy in 2. Further, comparing the ${ }^{1} \mathrm{H}$ and ${ }^{13} \mathrm{C}$ NMR data of C-2 to C-7 moiety of 2 with those of the same structural units in milbemycin $\beta_{3},{ }^{7-9}$ $\beta_{4},{ }^{10,11} \beta_{13}, \beta_{14}$, ${ }^{12}$ suggested that the C-2 to C-7 moiety in 2 was an aromatic ring as that of milbemycin $\beta_{3}, \beta_{13}, \beta_{14}$. The HMBC correlations (Figure 1c) from $\delta_{\mathrm{H}} 2.23(4-\mathrm{Me})$ to $\delta_{\mathrm{C}} 132.2(\mathrm{~d}, \mathrm{C}-3)$, $\delta_{\mathrm{C}} 122.8(\mathrm{~s}, \mathrm{C}-4)$ and $\delta_{\mathrm{C}} 156.1(\mathrm{~s}, \mathrm{C}-5)$, from $\delta_{\mathrm{H}} 2.07(8-\mathrm{Me})$ to $\delta_{\mathrm{C}}$ $144.3(\mathrm{~s}, \mathrm{C}-7), \delta_{\mathrm{C}} 134.8$ (s, C-8) and $\delta_{\mathrm{C}} 128.4$ (d, C-9) confirmed the presence of a phenyl ring in 2 . As a result, the gross structure of 2 was established as shown in Figure 1. Biogenetically, the relative configuration of $\mathbf{2}$ was assigned as that of $\mathbf{1}$.

In conclusion, we obtained two new doramectin analogs from the culture broth of $S$. avermitilis NEAU1069. Along with previously obtained analogs of doramectin, avermectin and milbemycin from S. avermitilis NEAU1069, ${ }^{3,4}$ we believe that these two new compounds possibly have important roles in understanding and perfecting the proposed biosynthetic pathways of avermectins and milbemycins.

\section{EXPERIMENTAL PROCEDURE}

\section{General procedures and reagents}

Melting points were measured using a Fisher-Johns micro-melting point apparatus (corrected; Fisher-Johns, Pittsburgh, PA, USA); UV spectra were obtained on a Varian CARY 300 BIO spectrophotometer (Varian, Palo Alto, CA, USA); IR spectra were recorded on a Nicolet Magna FT-IR 750 spectrometer (Nicolet Magna, Madison, WI, USA); ${ }^{1} \mathrm{H}$ - and ${ }^{13} \mathrm{C}-\mathrm{NMR}$ spectra were measured using a Bruker DRX-400 $\left(400 \mathrm{MHz}\right.$ for ${ }^{1} \mathrm{H}$ and $100 \mathrm{MHz}$ for $\left.{ }^{13} \mathrm{C}\right)$ spectrometer (Bruker, Rheinstetten, Germany); chemical shifts are reported in p.p.m. $(\delta)$ using the residual $\mathrm{CHCl}_{3}\left(\delta_{\mathrm{H}} 7.26 ; \delta_{\mathrm{C}} 77.0\right)$ as an internal standard, and coupling constant $(J)$ in $\mathrm{Hz} .{ }^{1} \mathrm{H}$ and ${ }^{13} \mathrm{C}-\mathrm{NMR}$ assignments were supported by ${ }^{1} \mathrm{H}-{ }^{1} \mathrm{H}$ COSY, HMQC and HMBC experiments. The ESI-MS and HRESI-MS spectra were taken on a Q-TOF Micro LC-MS-MS mass spectrometer (Waters, Milford, MA, USA). Optical rotation was measured on a Perkin-Elmer 341 Polarimeter (Perkin-Elmer, Fremont, CA, USA). Column chromatography was carried out on silica gel (100-200 mesh, Qing Dao Hai Yang Chemical Group, Qingdao, China). Semi-preparative HPLC (Agilent 1100, Zorbax SB-C18, $5 \mu \mathrm{m}, 250 \times 9.4 \mathrm{~mm}$ i.d.; Agilent, Palo Alto, CA, USA) was further performed to obtain pure compounds. All chemicals used in the study, such as methanol $(\mathrm{MeOH})$, ethyl acetate (EtOAc), petroleum ether $\left(60-90^{\circ} \mathrm{C}\right)$ and acetone, were of analytical grade.

\section{Strain fermentation, isolation and purification of compounds}

Details of the producing strain, S. avermitilis NEAU1069, were described in a previous paper. ${ }^{3,4}$ The strain was maintained on a YMS medium containing soluble starch (Bei Jing Ao Bo Xing, Beijing, China) $10 \mathrm{~g}$, yeast extract (Bei Jing Ao Bo Xing) $2 \mathrm{~g}, \mathrm{KNO}_{3} 1 \mathrm{~g}$ and agar $20 \mathrm{~g}$ in 1.01 tap water, $\mathrm{pH}$ 7.0. The seed medium consisted of glucose (Bei Jing Ao Bo Xing) $20 \mathrm{~g}$, soybean flour (Cormwin, Beijing, China) $15 \mathrm{~g}$ and yeast autolysate (Bei Jing Ao Bo Xing) $5.0 \mathrm{~g}$ in 1.01 tap water, $\mathrm{pH} 7.0$. Both the media were sterilized at $121^{\circ} \mathrm{C}$ for $20 \mathrm{~min}$. Slant cultures were incubated for $6-8$ days at $28^{\circ} \mathrm{C}$. A total of $10 \mathrm{ml}$ 
Table $1{ }^{1} \mathrm{H}$ and ${ }^{13} \mathrm{C}$ NMR data of compounds 1 and 2

\begin{tabular}{|c|c|c|c|c|}
\hline \multirow[b]{2}{*}{ Position } & \multicolumn{2}{|c|}{ Proton } & \multicolumn{2}{|c|}{ Carbon } \\
\hline & 1 & 2 & 1 & 2 \\
\hline 1 & & & $174.1 \mathrm{~s}$ & $169.6 \mathrm{~s}$ \\
\hline 2 & $3.45 \mathrm{~m}$ & & $47.9 \mathrm{~d}$ & $123.3 \mathrm{~s}$ \\
\hline 3 & $5.33 \mathrm{~m}$ & $7.40 \mathrm{~s}$ & $118.4 \mathrm{~d}$ & $132.2 \mathrm{~d}$ \\
\hline 4 & & & $138.6 \mathrm{~s}$ & $122.8 \mathrm{~s}$ \\
\hline 5 & $4.05 \mathrm{~m}$ & & $77.2 \mathrm{~d}$ & $156.1 \mathrm{~s}$ \\
\hline 6 & $\begin{array}{l}1.79 \mathrm{~m} \\
2.22 \mathrm{~m}\end{array}$ & $6.62 \mathrm{~s}$ & $37.1 \mathrm{t}$ & $114.2 \mathrm{~d}$ \\
\hline 7 & & & $76.2 \mathrm{~s}$ & $144.3 \mathrm{~s}$ \\
\hline 8 & & & $136.8 \mathrm{~s}$ & $134.8 \mathrm{~s}$ \\
\hline 9 & $6.27 \mathrm{~d}(10.8)$ & 5.71 br d (11.2) & $124.6 \mathrm{~d}$ & $128.4 \mathrm{~d}$ \\
\hline 10 & $6.00 \mathrm{dd}(10.8,14.8)$ & $6.08 \mathrm{dd}(11.2,15.0)$ & $126.2 \mathrm{~d}$ & $126.9 \mathrm{~d}$ \\
\hline 11 & $5.59 \mathrm{dd}(10.0,14.8)$ & $5.48 \mathrm{dd}(10.0,15.0)$ & $136.2 \mathrm{~d}$ & $135.7 \mathrm{~d}$ \\
\hline 12 & $2.45 \mathrm{~m}$ & $2.52 \mathrm{~m}$ & $40.7 \mathrm{~d}$ & $40.9 \mathrm{~d}$ \\
\hline 13 & $3.97 \mathrm{br} \mathrm{s}$ & $4.01 \mathrm{br} \mathrm{s}$ & $83.0 \mathrm{~d}$ & $82.9 d$ \\
\hline 14 & & & $135.0 \mathrm{~s}$ & $134.8 \mathrm{~s}$ \\
\hline 15 & $4.82 \mathrm{~m}$ & $4.09 \mathrm{br} d(10.2)$ & $117.5 \mathrm{~d}$ & $118.0 \mathrm{~d}$ \\
\hline 16 & $2.29 \mathrm{~m}$ & $2.25 \mathrm{~m}$ & $34.2 \mathrm{t}$ & $33.3 \mathrm{t}$ \\
\hline 17 & $3.75 \mathrm{~m}$ & $3.83 \mathrm{~m}$ & $68.4 \mathrm{~d}$ & $68.5 d$ \\
\hline \multirow[t]{2}{*}{18} & $0.74 \mathrm{q}(12.4)$ & 0.78 q (11.8) & $36.3 \mathrm{t}$ & $36.4 \mathrm{t}$ \\
\hline & $1.79 \mathrm{~m}$ & $1.96 \mathrm{~m}$ & & \\
\hline 19 & $5.31 \mathrm{~m}$ & $5.48 \mathrm{~m}$ & $67.2 \mathrm{~d}$ & $67.2 \mathrm{~d}$ \\
\hline \multirow[t]{2}{*}{20} & $1.47 \mathrm{t}(11.6)$ & $1.44 \mathrm{t}(12.0)$ & $40.6 \mathrm{t}$ & $40.8 \mathrm{t}$ \\
\hline & $1.90 \mathrm{dd}(4.8,12.4)$ & $1.96 \mathrm{~m}$ & & \\
\hline 21 & & & $99.6 \mathrm{~s}$ & $99.9 \mathrm{~s}$ \\
\hline \multirow[t]{2}{*}{22} & $1.65 \mathrm{~m}$ & $1.66 \mathrm{~m}$ & $41.2 \mathrm{t}$ & $41.2 \mathrm{t}$ \\
\hline & $1.96 \mathrm{dd}(2.8,14.0)$ & $1.96 \mathrm{~m}$ & & \\
\hline 23 & 3.68 br s & $3.77 \mathrm{br} \mathrm{s}$ & $70.0 \mathrm{~d}$ & $70.2 d$ \\
\hline 24 & $1.63 \mathrm{~m}$ & $1.65 \mathrm{~m}$ & $35.1 \mathrm{~d}$ & $35.1 \mathrm{~d}$ \\
\hline 25 & $3.38 \mathrm{~d}(10.0)$ & $3.41 \mathrm{~d}(11.6)$ & $72.5 \mathrm{~d}$ & $72.5 \mathrm{~d}$ \\
\hline 26 & $1.50 \mathrm{~m}$ & $1.52 \mathrm{~m}$ & $38.1 \mathrm{~d}$ & $38.1 \mathrm{~d}$ \\
\hline \multirow[t]{2}{*}{27} & $1.18 \mathrm{~m}$ & $1.23 \mathrm{~m}$ & $26.9 \mathrm{t}$ & $26.9 \mathrm{t}$ \\
\hline & $1.77 \mathrm{~m}$ & $1.77 \mathrm{~m}$ & & \\
\hline \multirow[t]{2}{*}{28} & $1.18 \mathrm{~m}$ & $1.23 \mathrm{~m}$ & $26.4 \mathrm{t}$ & $26.4 \mathrm{t}$ \\
\hline & $1.77 \mathrm{~m}$ & $1.65 \mathrm{~m}$ & & \\
\hline \multirow[t]{2}{*}{29} & $1.46 \mathrm{~m}$ & $1.52 \mathrm{~m}$ & $31.2 \mathrm{t}$ & $31.1 \mathrm{t}$ \\
\hline & $1.56 \mathrm{~m}$ & $1.65 \mathrm{~m}$ & & \\
\hline \multirow[t]{2}{*}{30} & $1.18 \mathrm{~m}$ & $1.23 \mathrm{~m}$ & $24.5 \mathrm{t}$ & $24.5 \mathrm{t}$ \\
\hline & $1.58 \mathrm{~m}$ & $1.60 \mathrm{~m}$ & & \\
\hline \multirow[t]{2}{*}{31} & $1.18 \mathrm{~m}$ & $1.23 \mathrm{~m}$ & $26.5 \mathrm{t}$ & $26.5 t$ \\
\hline & $1.65 \mathrm{~m}$ & $1.77 \mathrm{~m}$ & & \\
\hline 4-Me & $1.82 \mathrm{~s}$ & $2.23 \mathrm{~s}$ & $19.4 \mathrm{q}$ & $15.4 \mathrm{q}$ \\
\hline $5-\mathrm{OCH}_{3}$ & $3.37 \mathrm{~s}$ & & $56.8 \mathrm{q}$ & \\
\hline 8-Me & $1.72 \mathrm{~s}$ & $2.07 \mathrm{~s}$ & $13.3 \mathrm{q}$ & $18.3 \mathrm{q}$ \\
\hline 12-Me & $1.18 \mathrm{~d}(6.8)$ & $1.16 \mathrm{~d}(6.8)$ & $20.1 \mathrm{q}$ & $19.6 \mathrm{q}$ \\
\hline 14-Me & $1.55 \mathrm{br} \mathrm{s}$ & $1.58 \mathrm{br} \mathrm{s}$ & $15.7 \mathrm{q}$ & $15.6 q$ \\
\hline 24-Me & $0.90 \mathrm{~d}(6.8)$ & $0.91 \mathrm{~d}(6.8)$ & $13.8 \mathrm{q}$ & $13.8 \mathrm{q}$ \\
\hline $1^{\prime}$ & $4.78 \mathrm{~d}(3.6)$ & $4.81 \mathrm{~d}(3.6)$ & $95.0 \mathrm{~d}$ & $94.9 d$ \\
\hline \multirow[t]{2}{*}{$2^{\prime}$} & $1.51 \mathrm{~m}$ & $1.53 \mathrm{~m}$ & $34.0 \mathrm{t}$ & $33.9 \mathrm{t}$ \\
\hline & $2.23 \mathrm{~m}$ & $2.35 \mathrm{~m}$ & & \\
\hline $3^{\prime}$ & $3.60 \mathrm{~m}$ & $3.60 \mathrm{~m}$ & $78.3 \mathrm{~d}$ & $78.3 d$ \\
\hline $3^{\prime}-\mathrm{OCH}_{3}$ & $3.51 \mathrm{~s}$ & $3.52 \mathrm{~s}$ & $56.8 \mathrm{q}$ & $56.8 q$ \\
\hline $4^{\prime}$ & 3.17 t (9.2) & $3.18 \mathrm{t}(9.1)$ & $76.2 \mathrm{~d}$ & $76.2 \mathrm{~d}$ \\
\hline $5^{\prime}$ & $3.90 \mathrm{dd}(6.4,9.6)$ & $3.89 \mathrm{dd}(6.3,9.5)$ & $68.0 \mathrm{~d}$ & $67.9 \mathrm{~d}$ \\
\hline $5^{\prime}-\mathrm{Me}$ & $1.28 \mathrm{~d}(6.8)$ & $1.28(6.8)$ & $17.7 \mathrm{q}$ & $17.7 \mathrm{q}$ \\
\hline
\end{tabular}

of sterile water was added to the slant of the YMS medium. The spores were scraped and transferred onto a sterile tube containing glass beads; the spore suspension was then filtered through six layers of a sterile filter cheesecloth and adjusted to $10^{7}-10^{8}$ c.f.u. $\mathrm{ml}^{-1}$. A $2.0 \mathrm{ml}$ of the spore suspension was inoculated into a $250-\mathrm{ml}$ flask containing $25 \mathrm{ml}$ of seed medium and incubated at $28^{\circ} \mathrm{C}$ for $24 \mathrm{~h}$, shaken at 250 r.p.m. Then, $8.0 \mathrm{ml}$ of the culture was transferred into 1-1 Erlenmeyer flask containing $100 \mathrm{ml}$ of the producing medium consisting of corn starch (Cormwin) 10\%, soybean powder (Bei Jing Ao Bo Xing) 1\%, cotton flour (Cormwin) 1\%, $\alpha$-amylase (Bei Jing Ao Bo Xing) $0.02 \%, \mathrm{NaCl} 0.1 \%, \mathrm{~K}_{2} \mathrm{HPO}_{4} 0.2 \%, \mathrm{MgSO}_{4} 7 \mathrm{H}_{2} \mathrm{O} 0.1 \%$, $\mathrm{CaCO}_{3}$ 0.7\%, cyclohexanecarboxylic acid $0.1 \%, \mathrm{pH} 7.0$, before sterilization. Fermentation was carried out at $28^{\circ} \mathrm{C}$ for $12-13$ days on a rotary shaker at 250 r.p.m.

The fermentation broth (30l) was filtered. The resulting cake was washed with water, and both filtrate and wash were discarded. Methanol (101) was used to extract the washed cake. The $\mathrm{MeOH}$ extract was evaporated under reduced pressure to approximately 21 at $45^{\circ} \mathrm{C}$ and the resulting concentrate was extracted three times using an equal volume of EtOAc. The combined EtOAc phase was concentrated under reduced pressure to yield $25 \mathrm{~g}$ of oily substances. The residual oily substance was chromatographed on silica gel and eluted with a petroleum ether-acetone mixture (95:5-50:50, v/v). The fractions eluted with the petroleum ether-acetone mixture (95:5-75:25, v/v) were combined and evaporated to obtain a crude mixture. The crude mixture was applied to a silica gel column and eluted with a petroleum ether-EtOAc mixture (95:5-50:50, v/v) to give five fractions (A1-A5). Fraction A3 eluted with a mixture of petroleum ether-EtOAc $(75: 25, \mathrm{v} / \mathrm{v})$ was also subjected to silica gel eluting with a petroleum ether-EtOAc mixture (85:5-75:25, v/v) to give two subfractions $\mathrm{B} 1$ and $\mathrm{B} 2$.

Semipreparative HPLC (Agilent 1100, Zorbax SB-C18, $5 \mu \mathrm{m}, 250 \times 9.4 \mathrm{~mm}$ i.d.) was used to obtain pure compounds. The eluate was monitored using a photodiode array detected at $220 \mathrm{~nm}$, and the flow rate was $1.5 \mathrm{ml} \mathrm{min}$ mat $^{-1}$ at room temperature. Subfraction B1 eluted with a mixture of petroleum etherEtOAc $(75: 25, \mathrm{v} / \mathrm{v})$ was further separated by semipreparative HPLC using a solvent containing a $\mathrm{CH}_{3} \mathrm{OH}-\mathrm{H}_{2} \mathrm{O}$ mixture $(92: 8, \mathrm{v} / \mathrm{v})$ to obtain compound 1 $\left(t_{\mathrm{R}} 24.2 \mathrm{~min}, 40 \mathrm{mg}\right)$ and compound $2\left(t_{\mathrm{R}} 21.5 \mathrm{~min}, 11 \mathrm{mg}\right)$.

\section{Physicochemical properties of 1 and 2}

Compound 1 (Figure 1a) $\mathrm{C}_{44} \mathrm{H}_{68} \mathrm{O}_{11}$, white amorphous powder; melting point $153-155^{\circ} \mathrm{C} ;[\alpha]_{\mathrm{D}}^{25}+51$ (c 0.2, EtOH); UV (EtOH) $\lambda_{\max } \mathrm{nm}(\log \varepsilon): 200$ (4.57), 250 (4.18); IR (KBr), $v_{\max } \mathrm{cm}^{-1}: 3454,2929,2855,1714,1637,1452,1380$, $1341,1167,1099,990 ;{ }^{1} \mathrm{H}$ NMR $\left(400 \mathrm{MHz}, \mathrm{CDCl}_{3}\right)$ and ${ }^{13} \mathrm{C} \mathrm{NMR}(100 \mathrm{MHz}$, $\mathrm{CDCl}_{3}$ ) data see Table 1; ESI-MS $m / z 795[\mathrm{M}+\mathrm{Na}]^{+}$; HRESI-MS $m / z 795.4649$ $[\mathrm{M}+\mathrm{Na}]^{+}$, calculated for $\mathrm{C}_{44} \mathrm{H}_{68} \mathrm{O}_{11} \mathrm{Na} 795.4654$.

Compound 2 (Figure 1a) $\mathrm{C}_{43} \mathrm{H}_{62} \mathrm{O}_{10}$, white amorphous powder; melting point $146-148{ }^{\circ} \mathrm{C} ;[\alpha]_{\mathrm{D}}^{25}+124$ (c $\left.0.09, \mathrm{EtOH}\right) ; \mathrm{UV}(\mathrm{EtOH}) \lambda_{\max } \mathrm{nm}(\log \varepsilon): 200$ (4.81), 245 (4.41); IR (KBr), $v_{\max } \mathrm{cm}^{-1}: 3451,2928,2856,1701,1614,1503$, 1451, 1378, 1279, 1162, 997; ${ }^{1} \mathrm{H}$ NMR $\left(400 \mathrm{MHz}, \mathrm{CDCl}_{3}\right)$ and ${ }^{13} \mathrm{C} \mathrm{NMR}$ $\left(100 \mathrm{MHz}, \mathrm{CDCl}_{3}\right)$ data see Table 1; ESI-MS $m / z 761[\mathrm{M}+\mathrm{Na}]^{+}$; HRESI-MS $m / z$ $761.4225[\mathrm{M}+\mathrm{Na}]^{+}$, calculated for $\mathrm{C}_{43} \mathrm{H}_{62} \mathrm{O}_{10} \mathrm{Na} 761.4235$.

Acid hydrolysis of 1 . Compound $1(5.0 \mathrm{mg})$ was dissolved in $1 \mathrm{M} \mathrm{HCl}(1 \mathrm{ml})$ and then heated at $80^{\circ} \mathrm{C}$ for $4 \mathrm{~h}$. Aglycone was extracted with $\mathrm{CHCl}_{3}$ three times, and the aqueous residue was evaporated under reduced pressure. The residue and the sugar obtained from selamectin, by the above procedure, were analyzed by TLC using chloroform-methanol $(9: 1, \mathrm{v} / \mathrm{v})$ as a developing solvent. The spots were detected by spraying with anisaldehyde $-\mathrm{H}_{2} \mathrm{SO}_{4}$ reagent followed by heating, and the result showed that the two sugars have the identical $R_{\mathrm{F}}$ values $\left(R_{\mathrm{F}}=0.6\right)$.

\section{ACKNOWLEDGEMENTS}

This study was supported by the National Natural Science Foundation of China (no. 309771427, 310717150), the National Key Project for Basic Research (no. 2010CB126102) and the Key Science and Technology Program of Heilongjiang province (GA08B101-2). 
1 Demain, A. L. \& Sanchez, S. Microbial drug discovery: 80 years of progress. J. Antibiot. 62, 5-16 (2009).

2 Li, J. W. H. \& Vederas, J. C. Drug discovery and natural products: end of an era or an endless frontier? Science 325, 161-165 (2009).

3 Wang, M. et al. New $\beta$-class milbemycin compound from Streptomyces avermitilis NEAU1069: fermentation, isolation and structure elucidation. J. Antibiot. 62, 587-591 (2009).

4 Wang, X. J., Wang, M., Wang, J. D. \& Xiang, W. S. Isolation and identification of nove macrocyclic lactones from $S$. Avermitilis NEAU1069 with acaricidal and nematocidal activity. J. Agric. Food Chem. 58, 2710-2714 (2010).

5 Pacey, M. S., Dutton, C. J., Monday, R. A., Ruddock, J. C. \& Smith, G. C. Preparation of 13-epi-selamectin by biotransformation using a blocked mutant of Streptomyces avermitilis. J. Antibiot. 53, 301-305 (2000).

6 Dutton, C. J., Gibson, S. P., Kinns, M., Swanson, A. G. \& Bordner, J. Structure of Doramectin. J. Chem. Soc. Perkin Trans. 2, 403-408 (1995).
7 Aoki, A., Fukuda, R. \& Nakayabu, T. Antibiotic substances. US. 3,950,360, 13 April (1976).

8 Smith, A. B., Schow, S. R., Bloom, J. D., Thompson, A. S. \& Winzenberg, K. N. Total synthesis of milbemycin B3. J. Am. Chem. Soc. 104, 4015-4018 (1982).

9 Schow, S. R., Bloom, J. D., Thompson, A. S., Winzenberg, K. N. \& Smith, A. B. Total synthesis of Milbemycin $\beta 3$ and its C(12) Epimer. J. Am. Chem. Soc. 108, 2662-2674 (1986).

10 Nonaka, K., et al. New milbemycins from Streptomyces hygroscopicus subsp. aureolacrimosus: fermentation, isolation and structure elucidation. J. Antibiot. 53, 694-704 (2000).

11 Hood, J. D. et al. A novel series of milbemycin antibiotics from Streptomyces strain E225. I. discovery, fermentation and anthelmintic activity. J. Antibiot. 42, 1593-1598 (1989).

12 Xiang, W. S., Wang, J. D., Wang, X. J. \& Zhang, J. Two new $\beta$-class milbemycins from Streptomyces bingchenggensis: fermentation, isolation, structure elucidation and biological properties. J. Antibiot. 60, 351-356 (2007). 